\title{
Technology of social adaptation of students of the I course of pedagogical higher education
}

\author{
Gulnoza Mardieva ${ }^{1}$ \\ ${ }^{I}$ Tashkent State Pedagogical University, Tashkent, Uzbekistan
}

Email: mardiyeva_g@umail.uz

\begin{abstract}
This paper makes analyses of the technology of social adaptation of students. On this case, I year students of the higher education was discussed from different points. Theoretical and methodological points of the research were concluded from various points. Adaptation process and its technology were mentioned by different views of the researchers to make better developmental analyses in the further.

Keywords: tradition, traditional view/imagination, students, history of pedagogy, shaping, interior coverage, technology, training, method, means.
\end{abstract}

\section{INTRODUCTION}

The problem of adaptation is critical in every step of education. Because the process of adaptation is the main criteria in every step of continuous education.

Social adaptation of the freshman of pedagogical higher educational institutions is practiced in four stages:

1) affecting inter-personal stage. The successful adaptation of a student in this stage happens mainly due to adapting behavioral habits and traditions of the said academic group;

2) affecting inter-faculty stage. The successful adaptation of a student in this stage happens mainly due to adapting existing traditional systems, accepting or not accepting mutual conversation with faculty administration and professors;

3) affecting with higher educational institution (HEI) mutually stage. In this stage student adapts specific traditions and rules of higher educational institution and identifies or does not identify himself with higher educational institution;

4) stage of professional-traditions. This stage brings up students interior coverage and learning.

Basing on following technology it has been developed a special training to socialize the freshmen of pedagogical higher institutions:

I. The trainings based on adaptation as an information-acknowledgment. The main purposes of such trainings are to make students to interfere with other students and acquainting each other.

II. The trainings to result practices to develop inter-people communications. The main purposes of such trainings are to make students to go in to conversation with other students and to develop emphatic and communicational adaptations.

III. Trainings to shape behavior based on social norms. Basically, students have such social norms, but it is important to shape them in places where they are new.

It is demanded to direct the adaptation process of the freshman of pedagogical higher institutions purposely and systematically.

\section{THEORITICAL BACKGROUND}

It is known that one of the important tasks of each institution of higher education is to ensure the positive adaptation of freshmen to the new educational system, new social relations, as well as the successful development of student status.

The problem of adaptation matters at every stage of training, because at each stage of lifelong education, the adaptation process has both common and peculiar sides. And when it comes to adapting students to the conditions of a higher educational institution, it is necessary to indicate the following: 
- passing the process of students' adaptation, having complex dynamics, requires the interdependence of social and personal value ideas;

- The first year of study, and sometimes the second, for students are held in difficult situations;

- in the process of studying at a university, students develop a sense of self-awareness, the development of a system of value relations to the world around and existence (essence) continues;

- students form basic settings;

- the student years, characterized as organizational, methodological and psychological, are important stages of the professional and social-personal adaptation of students.

The deepening on a global scale of political, socio-economic, social and cultural development, the need to train highly qualified specialists - politically active citizens for building a free civil society, training personnel capable of working together in a market economy and competitive in the labor market makes it even more relevant the problem of educating teachers.

An effective solution to these problems is primarily associated with the ability of pedagogical educational institutions to meet the requirements of a changing society, the ability to form professionally significant qualities in future teachers.

It is known that among the applicants who submit documents to higher pedagogical educational institutions, there are those who do not act in order to master the profession of a teacher, and they are looking for opportunities in the future to work in different fields, to engage in other professional activities, so some are trained for receiving someone abstract education. Therefore, in some cases, effective academic performance, indicating a student's readiness for exams, is considered a positive completion of the adaptation process. Such a view is inappropriate. The process of absolute adaptation, the conscious acceptance by students of the values, criteria, goals and objectives that exist in higher pedagogical educational institutions, make it necessary to develop measures aimed at preparing to acquire the skills of pedagogical educational activity.

It is in the first year that students form their attitude to study, to future professional activities, actively "searching for themselves" continues. Even for students who have completed general secondary, specialized secondary education is excellent, a sense of faith in their own strength is not immediately formulated. Sometimes the first failures in many cases cause weakness, a pessimistic mood, and a lack of faith in the future. For this reason, the adaptation of freshmen to university conditions reflects an important problem.

To date, some models of adaptation of freshmen to the conditions of a higher educational institution have been developed. In particular, the phased model of the adaptation process developed by N.M. Egamberdieva covers the following structural parts:

- establishment of equilibrium - the appearance of equilibrium between an individual and the environment in the form of respect in relation to the existing system of values and norms of behavior;

- false adaptation - the unity of external adaptation to conditions and a negative attitude to its measures;

- addiction - recognition and acceptance of the values of the new environment;

- assimilation - mental reorientation of personality, transformation of previous views, orientations, attitudes ${ }^{1}$.

This model is conditional, the periods of adaptation depicted in it can be carried out simultaneously or complement each other.

B.R. Zhuraeva, the process of adaptation of future teachers to the new socio-cultural environment is divided into the following stages:

- the initial period: here the individual, the group knows how to behave in the existing social environment, but they are not yet ready to accept the value system of the new social environment, therefore they seek to maintain the old value system;

- the period of getting used to: the individual, the group try to develop a patient attitude towards the system of new values, the standards of behavior;

1 Эгамбердиева Н.М. Ижтимоий педагогика (Социальная педагогика). - Ташкент: Изд-во библ. им. А.Навои, 2009.- C.58 
- accommodation period, i.e. the period when the individual recognizes and accepts the basic elements of the new system of values of a given environment, and the environment, group, in turn, recognizes individual values of the individual;

- period of assimilation, i.e. the individual, group and environment are mutually harmonizing based on existing values.

M.N. Luzina developed the following strategies for adaptable behavior:

- active development of the existing value system in the environment;

- self-change;

- leaving this environment, look for a new one;

- break the connection with the environment and close in his inner world;

- own passive representation;

- poor addiction to environmental conditions;

- weakened expectation of external changes;

- weakened expectation of internal changes.

N.G. Ismatova suggested considering the content of adaptation from three points of view, taking into account the point of view of professional adaptation:

- physiological: function of organs and systems, endocrine regulation, regulation of nerves;

- socio-psychological adaptation: the formation of measures of a new psychological behavior, the correction of personal qualities in connection with the requirements; development of a new social environment;

- professional: accustom to new working conditions, pedagogical profession, accustom to constantly improve their knowledge and pedagogical skills.

\section{MAIN PART}

Based on the study and analysis of the above models, we determined the following three generalized degrees of adaptation of first-year students to university conditions:

- absolute adaptation. Full perception of values and criteria, goals and objectives of a higher educational institution, willingness to obey the rules of educational activity. Such students form the basis of the student community;

- mimicry. Not perceiving the goals and objectives of education, the basic rules of an educational institution are subject to secondary rules. This type of adaptation is inherent in the risk group. Students of this group are always ready to leave their studies at the university at any time;

- adaptive individualism. It is characterized by the fact that, taking basic criteria and values, they do not obey secondary rules.

Based on these degrees of adaptation, we have developed the following effective model for the adaptation of freshmen to the conditions of a pedagogical university (Fig. 1).

As can be seen from fig. 1, the social adaptation of freshmen at pedagogical universities is carried out on the basis of mutual influence and goes through four stages:

- stage of interpersonal influence. The effective adaptation of students at this stage is primarily associated with the development of the values and rules of behavior inherent in the academic group;

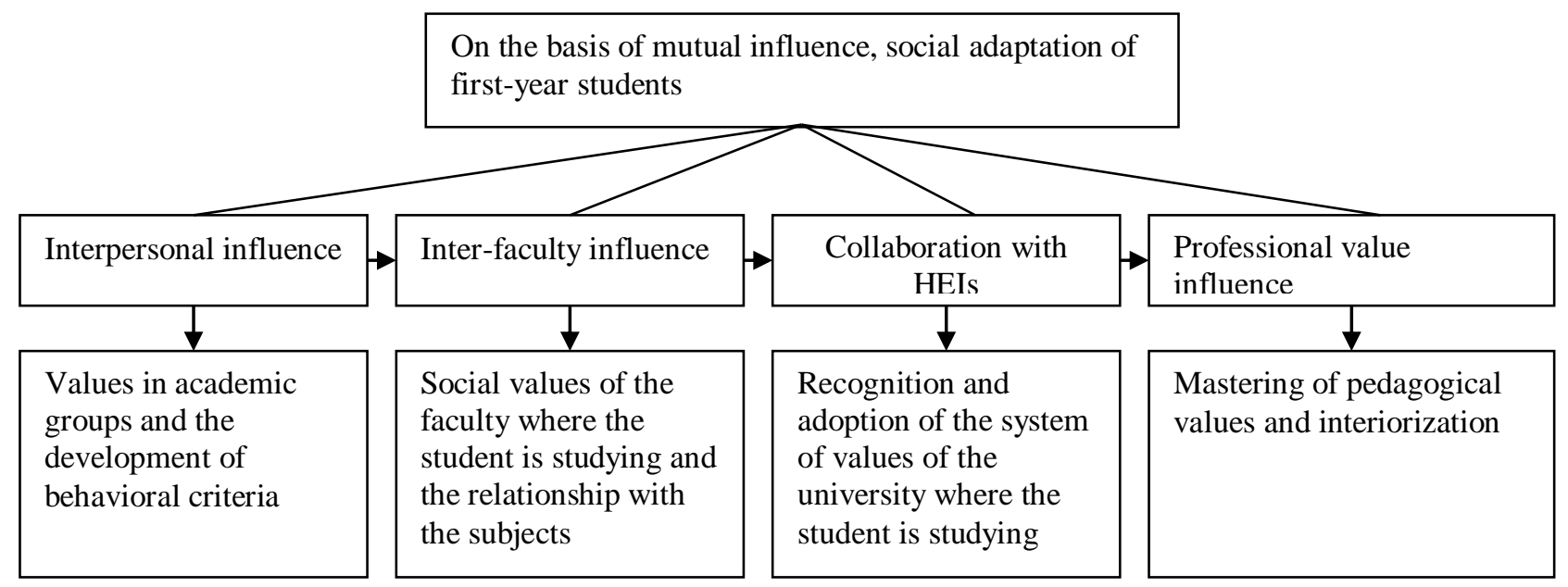

Fig. 1. An active (acting?) Model of social adaptation of first-year students of a higher pedagogical educational institution. 
- the stage of inter-faculty influence. Adaptation at this stage is associated with the adoption or non-adoption of the existing system of values at the faculty, methods of communication with the administration, and the faculty of the faculty;

- stage of interaction with the university. At this stage, the student masters the values, rules inherent in higher pedagogical educational institutions, identifies or does not identify himself with the university;

-professional-value influence. At this stage, the student develops educational values and internalizes.

Students from the first days of study at the university begin to get acquainted with a new life for them. In order to solve the problem of yesterday's high school graduates, academic lyceums and colleges effectively adapting to the new conditions, it is necessary to highlight the main problems that students face in the first year of study.

Based on the results of studies aimed at identifying problem situations faced by students of the first stage, we can distinguish the following, often encountered difficulties among students:

- an increase, and a significant, training load;

- the difficulty of mastering new subjects;

- difficulty communicating with fellow students;

- The formation of a new system of communication with the teaching staff.

One of the important social factors affecting the behavior of a first year student, his relationship with classmates and teachers is the need to get used to a changed social position, to new learning conditions, to a new status - the role of a university student. In addition, a number of crisis situations also arise that impede the successful adaptation of students in the new life environment. The crisis state that arises in the process of adaptation is negative emotional feelings that arise as a result of an inadequate reaction to the requirements set within the adaptation period.

The result of the controlled adaptation process and the targeted influence on the personality of the adaptant is the reason for the professional development of students, and also reduce the negative impact of crisis conditions.

In order to reduce the negative impact of crisis conditions, it is advisable to develop technologies aimed at increasing the degree of adaptation of subjects. Based on this, in the framework of the research, a technology was developed for the social adaptation of first-year students of pedagogical higher educational institutions (Fig. 2).

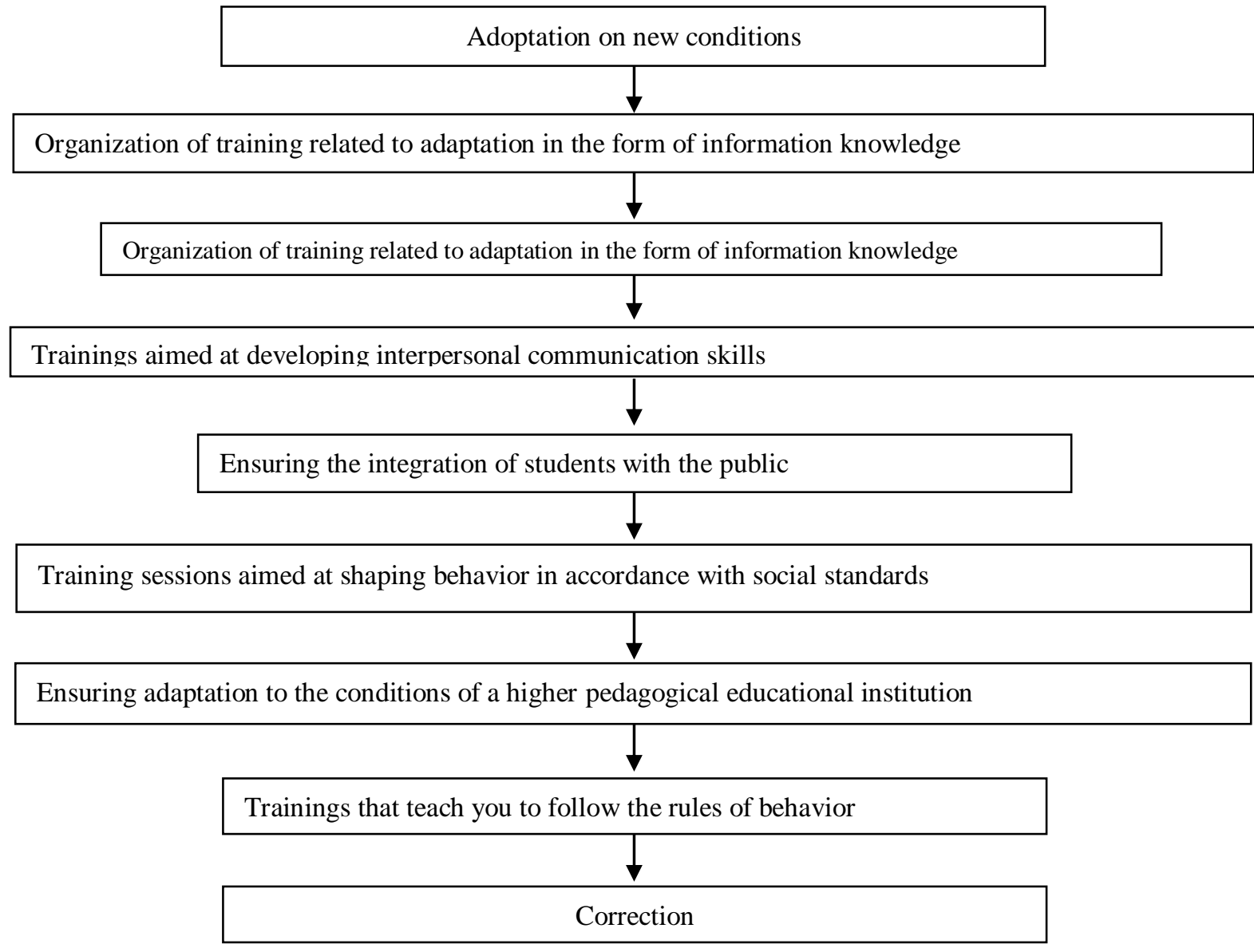

Fig. 2. Technology of social adaptation of first-year students of pedagogical universities. 
Based on this technology, a pedagogical higher educational institution has developed a number of training sessions aimed at the social adaptation of first-year students. We will dwell on some training sessions in more detail.

I. Training related to adaptation in the form of information knowledge

These trainings are organized with the aim of conducting active communication between students and the group, as well as meeting each other. For such dating games, themes are used: "Snow collection", "Apple", "Names - qualities", "Acquaintance in pairs", etc.

"Yor Yimimi" ("Collecting Snow"). At the direction of the coach, one of the participants, standing on the right or left, says his name. The second names the first participant and his own. The third participant names the first, second, and his own name. Thus, all participants in the training repeat. The last participant begins to name the first and subsequent in order and at the end calls his name. The students of the group are introduced in this way.

"Apple". Participants sit in a circle. The host starts saying "My name is ...", "I love ..." (he can name any thing or person), and then throws an apple (ball) to one of the participants sitting. The one who catches the apple calls himself what he loves and throws the apple to the next participant and continues throughout the circle until all the participants call themselves.

In the process of familiarization it is possible to say the following phrases: "I love ..." (someone or something), "Since childhood, I love to eat ... (something)", "I like ... (color, flower or fruit and etc.). "

"Names of quality." This game is aimed at raising the mood of participants, to ensure that participants feel comfortable. Each participant, naming the name of any person, also names the quality inherent in this name (for example, Behzod - a good son, Sherzod - courage, etc.).

"Acquaintance in pairs." The participants, having retired in pairs, tell each other about themselves for 10 minutes. And so on until all the participants find out information about each other.

II. Skills Training

interpersonal communication

The purpose of these training sessions is to develop students' skills in the ability to communicate in a group, as well as the communicative and empathic qualities of students.

"Politeness".

The purpose of the training: the formation of interpersonal communication skills in the group.

Materials: whatman, markers.

Situations:

1. What are the rules of communication (behavior) that exist in the environment where you spend your most time?

2. How do you greet each other, how do you thank each other?

3. With what gestures, signs do you show your gratitude?

4. With what gestures, signs do you express your discontent, disagreement?

5. Why do young people use words such as "thank you," "perhaps a hundred," "thank you," or "if it's not difficult for you ..."?

Training progress:

The trainer explains the tasks in the following way: let's try during the lesson to try the new method, which we will call "politeness". First we define a list of politeness rules. Within five minutes you should make your suggestions about the rules of courtesy. Then, we will discuss them and vote for the final (final) list. In order for the courtesy rules to be applied in a group, it is necessary to create a system of fines that you will develop yourself. You are given another 5 minutes to consider the punishments for those who do not follow the rules of politeness and violate them.

Each of the participants begins to work on compiling courtesy rules and develop a system of fines for violators of these rules.

Participants in the training voluntarily divide into groups and begin to discuss the rules and the system of punishments.

After the discussion, one of the group members begins the presentation of the rules that have been worked out and a system of penalties for those who do not follow the rules.

After the presentations of all groups, the most basic rules are selected and the system of fines developed by the participants is drawn up in a table.

"Nobility"

The purpose of the training: the formation of students' feelings of caring and nobility in relation to classmates and members of their group.

Materials: whatman, markers.

Situation. Despite the fact that nobility and the desire to live for themselves are contradictory qualities, a person possesses one and the other. Any generosity shown in relation to another person always remains in memory. Despite this, in every person there is a desire to live for himself, which slows down the desire for nobility. Let's compare these two principles. 


\section{Training progress:}

The trainer asks all participants to write their wishes on paper.

Then, each of them exchanges a sheet with a record with the next sitting participant. In the process of getting acquainted with the dreams and desires of a friend, a student should find answers to the following questions: a) What help could you provide to a friend so that his dream will come true ?, b) What could you refuse to make a friend's dreams come true? , c) What would you recommend to a friend so that his dreams come true?

Students then discuss their dreams in groups. After comparing desires, a diagram of the same desires and dreams is compiled. Then, the groups in turn present their desires and dreams and questions on their implementation.

"Helpers"

The purpose of the training: to educate students in a sense of mutual assistance, friendship and courage.

Situation. Let's tell each other to whom we helped for the last time. Who was he? Maybe this is your relative, or maybe a friend or a complete stranger? Well, what did this man remember? And now, remember the conditions in which this happened. Did the person ask for help or was this your initiative?

Who is willing to tell us about the disinterested help he provided?

During the performance, participants should pay attention to the presentation style, facial expressions of the speaker, pronunciation, etc.

"For each other"

The purpose of the training: to develop mutual cooperation between students, emotionally bring them together.

Materials: whatman, markers.

Situation. People are made for each other. This no longer requires evidence. If anyone wants, we can discuss this issue. The main objective of this study is that each member of the group thinks about where and what can benefit you. For example, you wrote the name Mansour and wrote on the contrary: "You can organize a business with him, travel and talk about football." Opposite the name of Sevard, you wrote that you can create a family with her, raise children, talk about theater, poetry and, of course, the secrets of cooking delicious dishes. Thus, you should analyze the list of each group member. Then, getting together, listen to each other. It will be interesting for everyone to find the answer to the question: "What am I capable of?"

"All - some - only I"

All are located on chairs arranged in a circle. The number of chairs should match the number of students participating. The coach is in the middle (no chair).

- Now I will tell some information about students. Everyone whom I say must relate to their seats and take up empty chairs. If the above concerns me, then I can also take someone's chair. A student left without a chair will become a leader. Let's try the test.

"Today we woke up in a good mood ...".

"Today came to study ...".

"She gathered her hair with golden braid ..." (A sign was selected regarding only one girl. When she got up, the host tried to sit in her place).

Then the presenter, as it were, "reveals the cards", explaining the event.

"I asked three questions." Some responded to the first question, others thought: "This does not concern me." In the second case, everyone answered. In the third - only one person. This game is called "All - some - only I".

The game continues in the same order. With this game, students will learn a lot of new information about each other.

"Dignity"

The purpose of the training: the formation of self-esteem, the ability to show oneself and the ability to communicate with the opposite side.

Materials: whatman, markers.

Training progress:

Initially, all students record their individual qualities on paper.

Then, the trainer asks one of the participants to read his list.

After the student reads the list of qualities, the coach asks one of the students to express an opinion about this person, that is, a feedback situation appears.

Students in the feedback process must adhere to the following rules:

- Feedback is provided only when you are asked to speak up;

- when you express your thoughts and feelings, you should clearly and clearly say what prompted you to speak in this way;

- you should not talk, insulting and insulting another; 
- do not advise, do not use phrases like: "If I were in your place ...", "You have to do ...".

This situation continues until all students read what they have written and feedback is implemented.

"Projective drawing"

Everyone is asked to draw two drawings - "What I Am," "What I Want to Be." Self-image is given 5 minutes. Pictures are not signed. The technical aspects of the figures are not significant. All drawings are laid out on the floor. Choose one drawing. It must be hung so that everyone can see. Then each participant takes turns talking about what he sees, what he feels, how the person who draws himself sees himself, what he would like to change in himself. The author of the picture does not say anything about himself. After everyone speaks out, you can try to identify the author of the picture. Then the author himself introduces himself, explains what he wanted to express in the drawing, and answers the replicas he liked. During the discussion, comments of the drawings pleasant to the authors are noted.

III. Behavioral Training

in accordance with public standards

Usually, students are already familiar with behavioral skills based on social norms, however, the use of these skills in new conditions is important. To achieve this goal, it is advisable to conduct the following classes with students.

1 training "What does it mean to be brought up?"

The purpose of the training: creating among students the accepted communication environment, to teach them to communicate with strangers with caution.

Questions for mental "attack":

1. What norms of behavior do you know (are listed, are written in a column)?

2. What norms do you not know, but would like to know?

3. Is it easy to master these standards?

4. What does it mean to follow the rules of behavior:

- perform normally, automatically;

- perform all the time in the same way, without linking with the situation;

- understand why you need to do this;

- when you follow them, restrain some feelings (give an example);

- think, understand something, know (?) what exactly do you think?

5. Why is it necessary to be brought up? Why are there rules of conduct?

Training progress:

Initially, students individually answer questions in writing.

Then divided into groups, discuss them together.

After that, the group answers are summarized, and a system of rules of behavior is formed. These questions do not express the upbringing of students and the fulfillment of norms by them automatically, but lead to an understanding of the total that norms:

- create among people an accepted environment of communication and living;

- a means to communicate with caution with other people;

- allow you to develop in yourself certain facets of character.

2 training "What kind of person am I?"

Presenter: a person usually likes to ask others questions. These questions may be about various things, but not about yourself. Today we will answer the question: "What kind of person am I?"

Take a piece of paper, write down and answer the following questions:

1. What are my main achievements and shortcomings?

2. What influence does my family have on me: father-mother, brothers, sisters and relatives?

The answers should be extremely frank, since no one reads your answers. If you allow me, I will read them. Thus, we collect ten answers. These answers will help you get to know yourself better.

At the last lesson, it became known that in order to behave properly in society, one needs not only to master the rules of behavior, but strive to form certain facets of character in oneself.

You need to work on yourself, but think about habits and character. In each of us, indeed, there are character traits that can prevent us from becoming educated and cultured people. These are the features we will try to determine.

You can test yourself in the following situations: "On the street with a polite smile, you help the old man to convey his purchases, and then after a while pushing two unfamiliar women, you will try to buy a ticket without waiting in line."

If you did so, do not hesitate: you act blindly (work for the public), you show yourself polite and cultured when you are comfortable and necessary, and that's all.

In fact, courtesy is not a festive dress, but everyday, every day of the week it should be clean and tidy. 
A culture of behavior is not a scenario for an amateur actor who wants to play the role of a cultured person. If you think that this is an endless masquerade of life (the main thing is to have time to change clothes), then you are also mistaken. In front of people, they strive to show themselves wellmannered, noble, and where no one sees them and does not make remarks, they, like a tornado, rush, scream, slam the door.

What character traits are manifested here? Having returned home (to the hostel), you, without changing your clothes, go to the refrigerator or to the table, take the first food that comes to your eye, or eat directly from the cauldron. After eating, wipe your mouth on the sleeve of the clothes and fall apart on a chair or sofa.

What do you think, how do you feel and how will you behave away? It may be like this: "the knife and fork" do not listen to you ", you drop them onto the floor; hands are automatically bent to wipe their mouth with a sleeve. However ... if you ate every day at home as expected, using a fork and knife, then, of course, it would be much easier for you. "

Conclusion

Good behavior requires daily exercise.

Stopping, resting at a break - not allowed.

If you behave differently at home and on the street, you can never become a cultural person.

What do you think, by what methods you can milk the same upbringing at home, and on the face, and at a party, and in public transport?

3 training "Successes of my friends and acquaintances and joyful events in their life"

The group is divided into subgroups. Each subgroup fills the table:

\begin{tabular}{|l|l|}
\hline Joyful events in my life & Success of my friends and acquaintances \\
\hline & \\
\hline & \\
\hline
\end{tabular}

Then several participants answer the following questions:

1. How do you respond to your friend's accomplishments?

2. How do you respond to your friend's achievement if it is higher than yours?

Now attention! answer yourself. Have you had this?

1. Your friend won a prize at the Olympiad (in mathematics, biology, native language). You know that you need to congratulate him, but you do not have the strength to do this. You feel bad that your friend is ahead of you, you would like to be in his place.

2. A friend (girlfriend) was presented with a new cell phone (or he / she bought (a)). He is happy and wants to share his joy with you.

How should you behave? Maybe, as a friendly person, you will say some kind words, praise the gift. Why instead we:

- show our indifference and even try not to look in his direction;

- they said angrily and with disdain: "There is nothing surprising, this is an old model" or "This is an antediluvian cell, where did you get it?"

What do you think, these actions and words, what qualities of a person testify to?

In this case, such a character trait of a person is manifested that if we try to suppress it, it will not allow us to be considered a worthy and educated person.

This is envy!

4 training "Sense of responsibility"

Questions for the "mental attack":

1. What is liability?

2. How do you understand responsibility?

3. What are your obligations: at home, in the family, in the hostel; on learning; in a relationship with friends; with whom else?

4. In what form and do you always carry them out?

5. Are you a disciplined (sensitive) person? Can you keep the secrets of others? Do you keep promises?

Do you do what you said?

6. Do you complete training tasks on time?

7. Do you have a habit of leaving urgent matters for "later"?

8. Was it so that the secret entrusted to you, you chatted to another?

All this testifies to the fulfillment of their obligations on time, the firmness of the word, non-interference in other people's affairs, modesty.

Imagine:

Each of us has a friend whose opinion we value. We try to impress him. We think about him, try to communicate more with him. Now, imagine this person is always with you and is following you. It 
changes you beyond recognition. Now you do not be rude to adults and do not quarrel with friends. Under the supervision of this person, it won't even occur to you to throw your socks into a corner, having come home after school, to give a lie, to lay a newspaper on the table, to be rude to a friend. Thus, the performance will help you to behave at home (or in the hostel) within the limits of decency, eat normally and be polite with people around you. At a certain time (you yourself will see for yourself) the bread in your dirty hands will no longer seem delicious. The lack of culture of your friends will annoy you, the mess will make you angry. After some time, you will feel that you are accustomed to good manners and this behavior has already turned into your inner need.

\section{Behavioral training}

The game "I never ..."

Purpose of the game: the formation of skills of students to think about themselves, to be able to see their achievements.

\section{RESULTS}

Participants should take turns saying a sentence that begins with the expression "I never ..." (for example, "I never smoked cigarettes", "I never rude adults", "I never used abusive expressions in a conversation", "I never walked in public with an embrace with a girl (guy)", etc.). While one participant speaks, others, if what they say is untrue to them, bend their fingers. For example, if someone still smokes, he bends his finger, and the other walks in an embrace with the opposite sex in public places, also bends his finger, etc. If after ten sentences someone has all or some fingers not bent, he wins.

The presenter must warn in advance that the proposals made must be vital and that when bending the fingers it is necessary to be extremely objective.

The game continues until everyone speaks out.

The Values Game

Purpose of the game: creating a hierarchy of personal values, awareness of the degree of their significance.

Conditions for the game: the lesson should be conducted under the calm, pacifying music. Of great importance is the tonality of the voice of the leader reading the text.

Course of the game: participants are given six pieces of paper and asked to write in accordance with the degree of significance of the most valuable in their lives. Then, the leaflets are mixed so that the sheet where the most valuable for the participant is written is at the very bottom.

The host invites participants to feel the loss of value written on the first sheet due to some circumstances. Then he asks, having crumpled this sheet, to throw it away and imagine his life without this value. Thus, participants abandon all values. Participants are then invited to recall what they felt when they lost a particular value. Then the leader announces that a miracle happened, an opportunity appeared to return all the valuables, and all the crumpled papers are returned one by one.

The presenter asks to compare the condition of the participants in the loss of values with what is written in the crumpled papers, and to say whether these returned values, written on paper, have lost their value for the participants. If members of the group have swapped places of importance for some values, they should inform the facilitator about this.

\section{CONCLUSION}

At the end of the lesson, the facilitator discusses the results and draws a conclusion.

Attention! During the lesson, participants can experience strong emotional states and feelings. Therefore, the lesson should be conducted out of excessive noise, in silence, participants should not interfere with each other, attention must be paid so as not to interfere with the lesson from the outside. The host must be attentive to the participants in the game.

\section{REFERENCES}

1. D. K., A., N.M., K., \& R.Sh., B. (2019). Modern problems of linguistics and methods of teaching English language. International Journal on Integrated Education, 2(6), 15-17. Retrieved from http://journals.researchparks.org/index.php/IJIE/article/view/188

2. Majumdar, A. (2019). Thirty years after the fall of the Berlin wall in Germany and celebration. American Journal of Economics and Business Management, 2(4), 61-73. https://doi.org/https://doi.org/10.31150/ajebm.v2i4.90 
3. Boychayeva, D., Rahmanova, D., \& Yuldasheva, M. (2019). Modern methods of teaching foreign languages to the university. International Journal on Integrated Education, 2(6), 18-20. Retrieved from http://journals.researchparks.org/index.php/IJIE/article/view/189

4. Nodira Gulomjonovna, N., \& Mahbuba Sobirjonovna, M. (2019). Peculiarities of using shrines in Fergana Valley for the Purpose of Tourism. International Journal on Integrated Education, 2(6), 1-4. Retrieved from http://journals.researchparks.org/index.php/IJIE/article/view/186

5. OmotayoJohncally, A., \& Bankole, A. (2019). On mathematical models for pension fund optimal selection strategies. American Journal of Economics and Business Management, 2(4), 26-60. https://doi.org/https://doi.org/10.31150/ajebm.v2i4.91

6. Hulkarbonu Yokubovna, Y. (2019). Evaluation of the economic impact of local population in the development of regional economy: an example of Chadak village. American Journal of Economics and Business $\quad$ Management, 2(3), https://doi.org/https://doi.org/10.31150/ajebm.v2i3.83

7. Dilorom Sobirovna, Q., Abdurasul Abdugafarovich, S., \& Baxtiyarjon Bulturbayevich, M. (2019). Improvement of the strategy of vertical integration in industrial enterprises. American Journal of Economics and Business Management, 2(3), 63-68. https://doi.org/https://doi.org/10.31150/ajebm.v2i3.81

8. Sevara Abdinazarovna, B. (2019). Contents of improvement of educational education and problems of education. American Journal of Economics and Business Management, 2(4), 74-87. https://doi.org/https://doi.org/10.31150/ajebm.v2i4.93 